\title{
PARADIGMS IN MANAGING PEOPLE: A TRIBUTE TO YOSHIO KONDO
}

\section{PARADIGME U UPRAVLJANJU LJUDIMA: U ČAST YOSHIOU KONDU}

\author{
Narayanan Ramanathan \\ IAQ-Academician \\ Independent Counsellor in Quality-based Management \\ \& Advisor (TQM), SRF Limited, Bengalore, India/Indija \\ E-mail: ram@100water.org
}

\author{
UDK/UDC: $005.331+005.6$ \\ JEL klasifikacija/JEL classification: M12; L15 \\ DOI: $10.30657 /$ hdmk.2020.01 \\ Pregledni članak/Review \\ Jezik/Language: Engleski/English
}

\begin{abstract}
When Yoshio Kondo was elected Honorary Member of ASQ in the year 2004, the citation underscored his outstanding contribution to human motivation and total quality management. His book in Japanese, Ohanashi Motivation, published in 1989, was soon translated into English in 1991 as Human Motivation. Scholar that Kondo was, his book drew on the contributions of others before him, especially Eizaburo Nishibori, Abraham Maslow, Frederick Herzberg and James O'Toole. Nishibori's triune model incorporates creativity, physical activity and sociality. This model corresponds with the I-We-It triad of Ken Wilber, which has profound implications for avoiding a fragmented view of humanity. Connected to Japan Standards Association, Kondo redefined a standard such that while objectives are clarified and constraints identified, a standard provides essential freedom to individuals, except for beginners. This is the concept of providing space, so very vital to human growth. On the other hand the creative breaking away from prescription by adepts is envisaged in the hierarchy of shu-ha-ri in Japanese, with equivalents in Chinese and Indian traditions. Not only do meaningful objectives lead to greater alignment, they also stimulate gretaer interest in what other related groups are doing, helping build sociality and teamwork in an organization. Kondo investigates sporting activity to draw lessons for work, because as in sports, struggles enhance the 'joy of achievement'. That is similar to the concept of pushing at the boundaries of our comfort zones in order to accomplish anything worthwhile. In addition to the above concepts, we could consider intrinsic motivation (Deming), natural hierarchies in human existence (Gebser, Graves), as well as the idea of immersing in the gemba (Shiba). These draw us to an understanding about the true needs of people at different levels of existence, and the ways to building momentum in an organization, and of course, performance. It should be clear that organizational performance is not the sum of individual ones, but the level of organizational capability actually determines the range of possible performance. When all three elements of I-We-It are reasonably balanced, people report that they are actually 'happy' working in their organization. The presentation will take a look at realfigures in this regard from a company, in addition to exploring the paradigms that produce great people management from literature and experience.
\end{abstract}


Key words: I-We-It, Natural hierarchies, space, comfort zone, intrinsic motivation.

\section{INTRODUCTION}

If you have a partial, truncated, fragmented map of the human being, you will have a partial, truncated, fragmented approach to business, medicine, spirituality, and so on. ${ }^{1}$

For all the voluminous literature on the subject, especially in the Anglo-Saxon world, managing people - 'human resources' as they are called - has not been a happy experience for many organizations. Part of the problem has been that ' $\mathrm{HR}$ ' is taught as though the underlying 'essences and principles', ${ }^{2}$ or paradigms, do not matter. Implicit and unstated assumptions about human beings turn current HR lore into dogma. In organizations that have chosen to be qualitycentered, these assumptions may either get challenged, or allowed unsuspectingly to hinder the quality-based approach to management. The great doctrines of the humanist era researchers Frederick Herzberg, ${ }^{3}$ who separated satisfiers from dissatisfying factors, or Abraham Maslow ${ }^{4}$ who postulated a hierarchy of human needs, or Douglas McGregor ${ }^{5}$ who elucidated Theories X and Y, to mention a few - are often venerated but seldom incorporated into the HR system.

This paper is written as a tribute to Yoshio Kondo whose lifetime work in quality included a much-acclaimed book Human Motivation (1991), or Ohanashi Motivation (1989) in Japanese. Its purpose is to explore a set of people-related paradigms which could profoundly impact the way HR management is conceived.

\section{THE I-We-It TRIAD}

Kondo describes the triune model of work (Figure 1) developed by Eizaburo Nishibori, whose writings are in Japanese.

This model, it can be seen, is but an expression of the more generic I-We-It model put forth by the philosopher Ken Wilber. ${ }^{6}$ Modernism is dismissive about whatever is subjective, and it ignores philosophers like Michael Polanyi ${ }^{7}$ who wrote: "Complete objectivity as attributed to [even] exact sciences is a delusion and is in fact a false ideal." Nishibori's model unapologetically embraces subjectivity as integral to its view of work.

\footnotetext{
${ }^{1}$ Ken Wilber, A Brief History of Everything, Shambhala, Boston, 1996, $2^{\text {nd }}$ edition, 2000.

${ }^{2}$ Peter Senge, The Fifth Discipline, Doubleday Currency,1990.

${ }^{3}$ Frederick Herzberg, One More Time: How do you Motivate Employees, Harvard Business Press, Boston, 2003, Harvard Business Review Classics, 2008.

${ }^{4}$ Abraham Maslow, Toward a Psychology of Being, 1954, Third Edition Wiley, Kindle Edition 1988, and Motivation and Personality, 1962, Third Edition, Longman, 1987.

${ }^{5}$ Douglas McGregor, The Human Side of Enterprise, Tata McGraw Hill, 1960, $7^{\text {th }}$ Reprint, 1983.

${ }^{6}$ Ken Wilber, Sex, Ecology, Spirituality, Shambhala, Boston \& London, 1995, $2^{\text {nd }}$ edition, 2000 and A Brief History of Everything, Shambhala, Boston, 1996, $2^{\text {nd }}$ edition, 2000.

${ }^{7}$ Michael Polanyi, 1958, 1962, Personal Knowledge, The University of Chicago Press, Paperback edition, 1974.
} 
Figure 1: Kondo's version of Nishibori's Model of Work

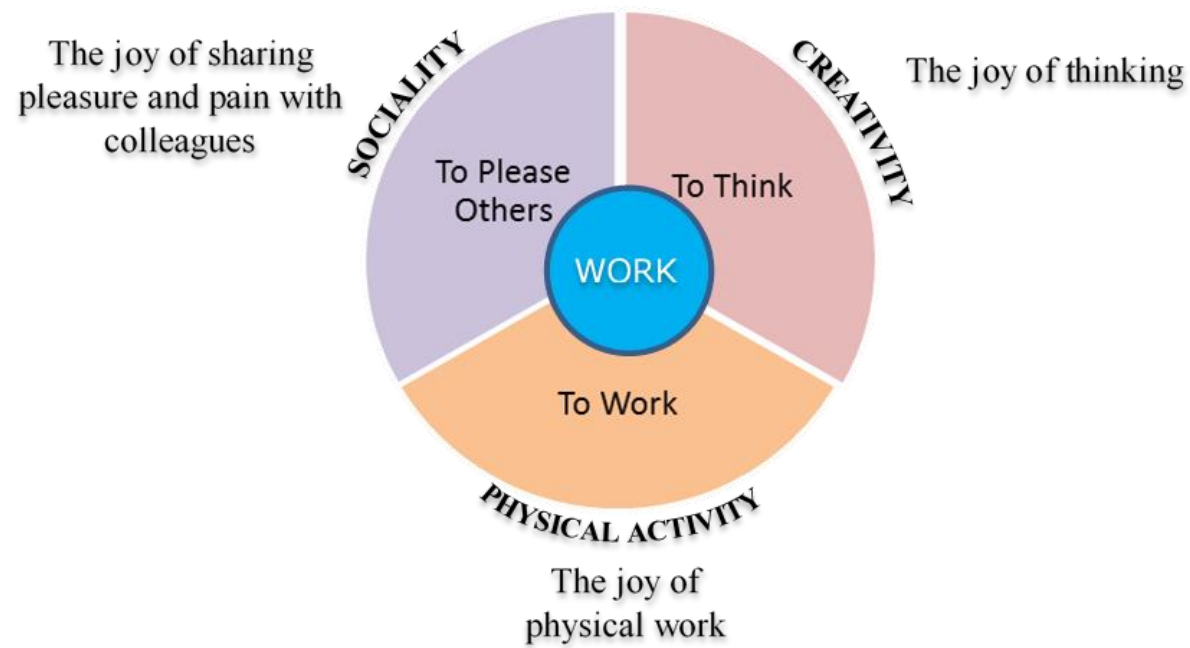

Wilber created a $2 \times 2$ matrix of the interior and the exterior versus the individual and collective as a means of grasping all of reality simultaneously and at once. He collapsed the four parts into three by combining the individual and collective exteriors as ' $I t$ '.

Fig. 2 The I-We-It Model

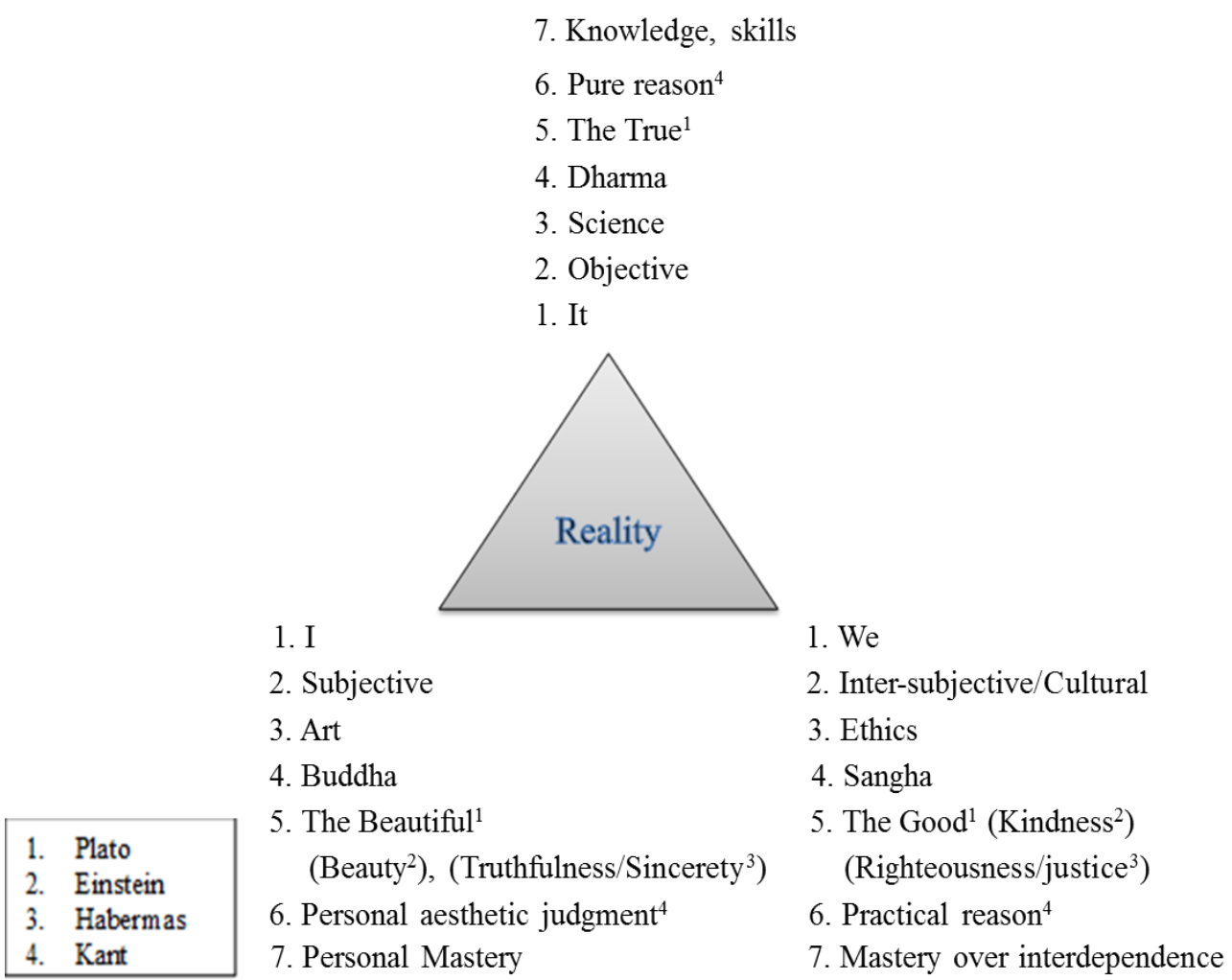


The subjective-personal is termed ' $I$ ' and the subjective-collective is termed 'We'. The expression of reality is not bestowed only on the It domain, for it is present in all the three; and the disregard for any one leads inevitably to a truncated view of reality.

Wilber thus created the 'Big Three', I, We, It. He called the three domains subjective, intersubjective and objective, He also showed this model's equivalence with the Buddhist triad of Buddha, Sangha and Dharma; with Science, Art and Ethics (or Morals); with Plato's triad of the True, the Good, the Beautiful; with Habermas's Truth, Truthfulness or Sincerity and Righteousness or Justice; and with Immanuel Kant's Pure Reason, Practical Reason, Personal aesthetic judgment. To this we may add Einstein's ${ }^{8}$ Kindness, Beauty and Truth. We can thus build a rich model of IWe-It, as in Figure 2. ${ }^{9}$

\section{NATURAL HIERARCHIES}

Through observations of children, clinical psychologist Jean Piaget ${ }^{10}$ outlined stages in the development of children in his books from 1923 through 1950, which have profound implications for adult development too. The psychiatrist Erik Erikson ${ }^{11}$ also developed his 'epigenetic chart' of eight steps in human development as the person interacts with a widening social radius. But of natural hierarchies in the growth of individuals, the most commonly cited is that of Abraham Maslow $^{12}$ who studied psychological health, and in the process investigated the needs that motivate people. Maslow identified five steps of consciousness terminating at the self-actualizing stage, which he saw was attained by less than one percent of people, the others being obstructed by deficiencies in fulfillment of needs at earlier stages, their neuroses. Maslow was able to describe in detail the characteristics, behaviour and 'peak experiences' of such fulfilled people, thus bringing to fore the study of psychological health.

Hierarchies have ancient antecedents, but their systematic characterization has proliferated now. They have developed in two parallel streams - those conceived by philosophers and those by psychologists. The ancient Indian tradition of the five koshas or sheaths (Here a translation from Adi Shankara, $8^{\text {th }}$ century C.E., by Tejomayananda, ${ }^{13}$ matches closely with Maslow's, as shown in Figure 3. Maslow seems to theorize that if needs at each stage are satiated, and deficiency-based psychopathologies are not accumulated, then self-actualization should be naturally possible. V.S. Mahesh ${ }^{14}$, perhaps reflecting the Eastern viewpoint, suggests instead that people who realize their potential are able to set low threshold limits on their satisfaction, rather than await satiation at each level. They thus avoid getting slanted like a tree that bends towards sunlight when blocked by a ledge. This stooping too is shown in Figure 3.

\footnotetext{
${ }^{8}$ Albert, Einstein, Ideas and Opinions, 1954, Rupa \& Co. 1979, 12 ${ }^{\text {th }}$ impression 1995, Copyright Crown Publishers 1954.

${ }^{9}$ Narayanan Ramanathan, The I-We-It of Adaptability, Paper presented in EOQ Congress, Gothenburg, 2014.

${ }^{10}$ Jean Piaget, The Essential Piaget, Basic Books, New York,1977.

${ }^{11}$ Erik H. Erikson, Childhood and Society, W. W. Norton \& Co., 1950, reprint by Penguin Books, England, 1973.

${ }^{12}$ Abraham Maslow, Toward a Psychology of Being, 1954, Third Edition Wiley, Kindle Edition 1988, and Motivation and Personality, 1962, Third Edition, Longman, 1987.

${ }^{13}$ Swami Tejomayananda, Translation and commentary, Tattvabodha, Adi Shankara's Sanskrit text of $8^{\text {th }}$ century C.E., Central Chinmay Mission Trust, 2005.

${ }^{14}$ V. S. Mahesh, Thresholds of Motivation, Tata McGraw Hill, New Delhi, 1993,
} 
Figure 3: Ancient Indian and Maslow hierarchy amended by V.S. Mahesh

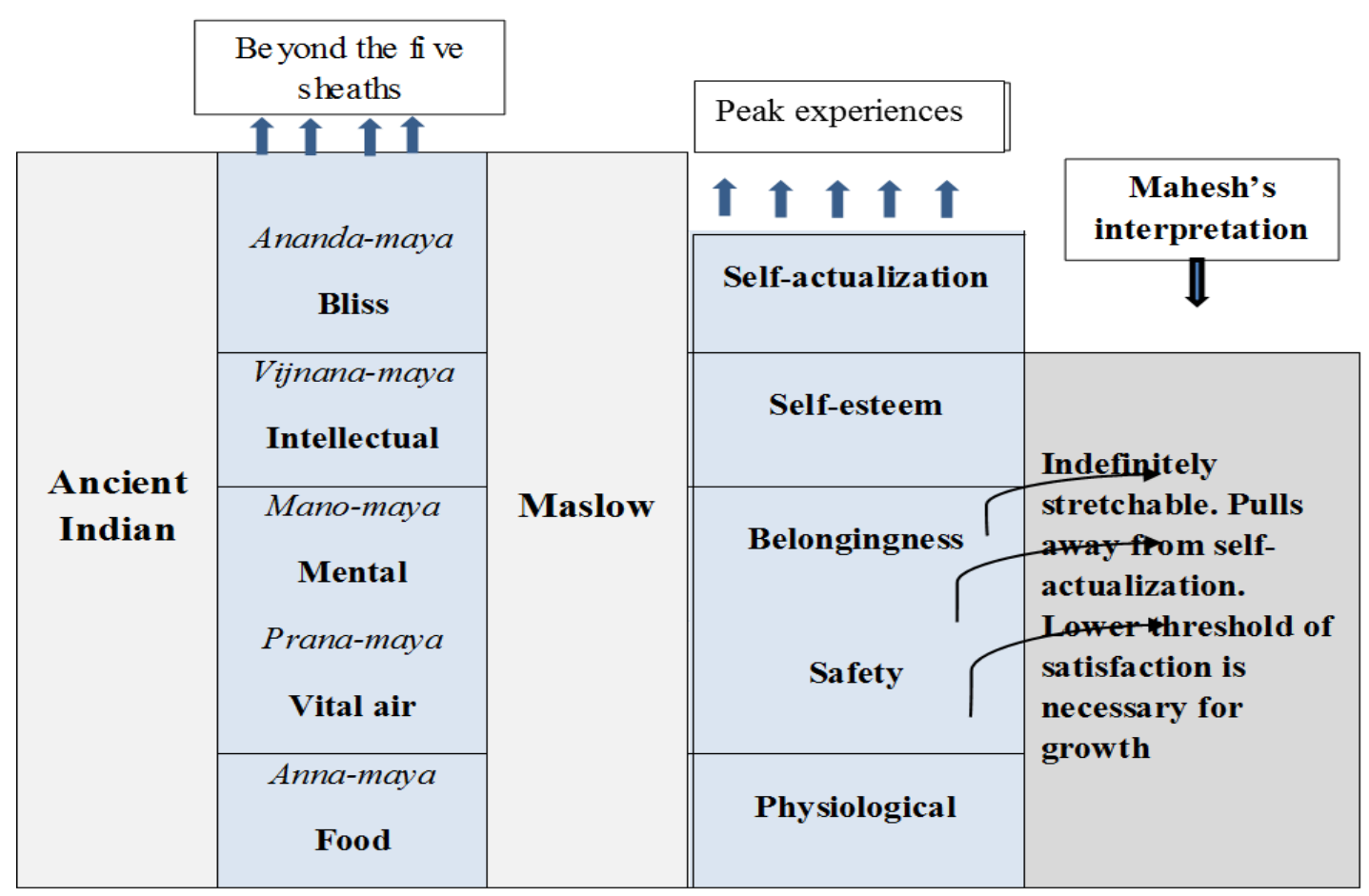

Philosophers have delineated the stages in the progression of mankind through the ages. Plotinus did so in the $3^{\text {rd }}$ Century CE, while in the twentieth century Aurobindo compiled a similar hierarchy from ancient traditions. The credit for a modern hierarchy should go to the philosopher Jean Gebser. ${ }^{15} \mathrm{He}$ categorized the advancement of humanity in terms of successive mutations to higher structures, starting with the archaic, and moving up to magic, mythical and mental, and declared that the current transition is to the integral stage. He describes the integral stage as 'aperspectival' in that it transcends perspective that had been the gift of the mental stage, which in turn had emerged from pre-perspectival stages. Each transition is of a quantum nature.

Wilber expanded the Gebser to levels below the archaic, and then expanded it by four levels above the integral - the spiritual realms - the psychic, subtle and the causal, leading to the nonstage, the non-dual. For Maslow, all of these belonged to 'peak experiences'. Wilber's stages in the subjective-individual realm roughly match Maslow's, his 'vision-logic corresponding to Maslow's self-actualizing. Wilber widened the hierarchy to four, correlating the subjective and objective interiors and exteriors. The rational level, for instance, corresponds to industrial in the objective-collective quadrant, and 'formop', (formal-operational) in the subjective-individual. Similarly, centauric correlates to informational and vision-logic. The post-mental stages are transrational (that is, for Wilber, transcending, but including the rational), even though many (ironically, Gebser included, at times) confuse it with the pre-rational. The Gebser-Wilber stages are shown in Figure 4.

${ }^{15}$ Jean Gebser, 1949, 1953, The Ever-Present Origin, Ohio University Press, Athens, English Translation, 1985. 
Figure 4: The hierarchies of Gebser and Wilber

\begin{tabular}{|l|l|l|l|l|l|}
\hline \multicolumn{2}{|c|}{ Subjective-collective } & \multicolumn{1}{c|}{$\begin{array}{c}\text { Subjective- } \\
\text { individual }\end{array}$} & \multicolumn{1}{c|}{ Objective-collective } \\
\hline \multicolumn{2}{|c|}{ Gebser's hierarchy } & & \multicolumn{3}{c|}{ Wilber's hierarchies } \\
\hline Post-perspectival & Integral & Centauric & Vision-logic & Informational \\
\hline Perspectival & Mental & Rational & Formop & Industrial \\
\hline \multirow{4}{*}{ Pre-perspectival } & Mythical & Mythic & Conop & Early state, empire; agrarian \\
\cline { 2 - 6 } & Magic & Magic & Concepts & Tribal/Village; horticultural \\
\cline { 2 - 6 } & Archaic & Archaic & Symbols & Tribes; foraging \\
\hline
\end{tabular}

The psychologist Clare Graves ${ }^{16}$ in a 1971 seminar in Washington, D.C., the notes of which were fortuitously transcribed by William R. Lee, presented the outcome of some twenty years of silent research regarding what constitutes psychological health. Well-versed with Maslow's work, Graves had research data to show that psychological health is not a state but a process that swings in a cycle of alternating adjustive and self-expressed stages. This was a new angle that revealed problems with Maslow's hierarchy, which has no alternating waves.

In comprehending the natural hierarchies in human development, the work of Graves is seminal. Graves was probably before his time and his work may have gone into obscurity if Don Beck and Christopher Cowan ${ }^{17}$ had not developed his theory into 'Spiral Dynamics', steps that swing in spirals, and named after colours, hopefully to skirt value judgments. Their work was backed by research across continents that found common pathways among diverse cultures. Many of these correspond to the Wilber stages, though like Gebser as well as Graves, but unlike Wilber, Beck and Cowan truncate their stages short of the spiritual domains as well as the 'pre-human'. They also were able to estimate the proportion of people in the world today (by no means equal across the world) in each stage. In addition, they judged the proportion of power held by people at each stage today. Thus, the Beck \& Cowan model could widen the scope of the Graves Model to the subjective-collective, to which they could find some objective correlates across cultures. These two models are shown in Figure 5, along with a possible comparison with the levels of Wilber.

The bulk of the world is centralized today at Mythic/Rational levels and crossovers, that is Blue and Orange. Reflection will show how this has shaped the way the human world runs today. It will be clear that the motivational patterns of persons and societies change radically with changes in levels, ${ }^{18}$ which are indeed of a quantum nature. Also, while Maslow was looking at burning our neuroses so that we could realize our potential, it may be that the societal 'mutations' ${ }^{19}$ to higher levels may be involuntary, and dependent on historical conjunctures, for there is the question of the overall stage of the society in which the individual is growing. Maslow ${ }^{20}$ too saw it: “... society or a culture can be either growth fostering or growth-inhibiting."

\footnotetext{
${ }^{16}$ Clare W. Graves, Levels of Human Existence, 2002, from transcribed notes of a 1971 Graves seminar by William R. Lee, ECLET Publishing, $5^{\text {th }}$ Reprint, 2009, with Foreword by Christopher Cowan.

${ }^{17}$ Don Edward Beck \& Christopher C. Cowan, Spiral Dynamics, Blackwell Publishing, 1996, Paperback edition, 2006.

${ }^{18}$ Clare W Graves, Helen Madden and Lynn P. Madden, The Congruent Management Strategy, From the Historical collection of the work of Dr Clare Graves by William R. Lee, 1970. www.claregraves.com

19 Jean Gebser, 1949, 1953, The Ever-Present Origin, Ohio University Press, Athens, English Translation, 1985.

${ }^{20}$ Abraham Maslow, Toward a Psychology of Being, 1954, Third Edition Wiley, Kindle Edition 1988, and Motivation and Personality, 1962, Third Edition, Longman, 1987.
} 
Figure 5. Graves and Beck \& Cowan hierarchies compared

\begin{tabular}{|c|c|c|c|c|c|c|}
\hline \multirow{2}{*}{\multicolumn{2}{|c|}{$\begin{array}{l}\text { Levels of Human } \\
\text { Existence - Graves }\end{array}$}} & \multirow{2}{*}{\multicolumn{2}{|c|}{ Beck \& Cowan Characterization }} & \multicolumn{2}{|c|}{$\begin{array}{c}\text { Beck \& Cowan } \\
\text { Distribution }\end{array}$} & \multirow{3}{*}{$\begin{array}{l}\text { Some Wilber } \\
\text { Equivalents? } \\
\text { Centauric } \\
\end{array}$} \\
\hline & & & & \multirow{2}{*}{$\begin{array}{c}\begin{array}{c}\text { \% of } \\
\text { People }\end{array} \\
0.1 \\
\end{array}$} & \multirow{2}{*}{$\begin{array}{c}\begin{array}{c}\% \text { of } \\
\text { Power }\end{array} \\
1 \\
\end{array}$} & \\
\hline Adjustive & H-U & Turquoise & Holistic & & & \\
\hline Expressive & G-T & Yellow & Systemic & 1 & 5 & Rational/Centauric \\
\hline Adjustive & F-S & Green & Communitarian & 10 & 15 & Rational \\
\hline Expressive & E-R & Orange & Entrepreneurial & 30 & 50 & Rational \\
\hline Adjustive & D-Q & Blue & Authoritarian & 40 & 30 & Mythic \\
\hline Expressive & C-P & Red & Exploitative & 20 & 5 & Magic/Mythic \\
\hline Adjustive & B-O & Purple & Tribal & 10 & 1 & Magic \\
\hline Expressive & A-N & Beige & Semi-stone age & 0.1 & 0.1 & Archaic \\
\hline
\end{tabular}

Graves proved that the levels of existence are independent of intelligence. Yet, the problemsolving capabilities at the G-T level exceeded the capability of all preceding levels put together. What is more, at the 'Being' levels of G-T and above, dogmatism falls off and so does egotism. Wilber too shows that moving up these levels connotes lessening egocentrism.

\section{I-We-It COMBINED WITH HIERARCHY}

How are the subjective-objective and individual-collective domains reflected in different hierarchies? This would be a subject fit for research. Blue level management would typically be bureaucratic. Employees at this level show dependency and seek safety and might prefer to be led. The American consultant Peter Block ${ }^{21}$ characterizes bureaucracy as believing in the justness of patriarchal contract, submission to authority, denial of self-expression, and sacrifice for unnamed future rewards - this last being practically identical to Graves' description of the D-Q level.

The business world today has largely evolved into the Orange level, with its rationality and money orientation. It is an egoic level, alternating between achievement and hedonism, while the collective position is both rational and money-oriented. Individual behaviour is competitive and conditioned to external rewards, and the culture promotes market economy and the pursuit of selfinterest in a system that is profit-driven. And this level exerts the greatest power in the world of today. In Figure 6 is 'Theory Orange' - a theory of what the interiors of the corporate world are, and how it behaves in the exteriors.

${ }^{21}$ Peter Block, The Empowered Manager, John Wiley \& Sons, 1987, New Edition, 1991. 
Figure 6. Theory Orange Reality for the Corporate World

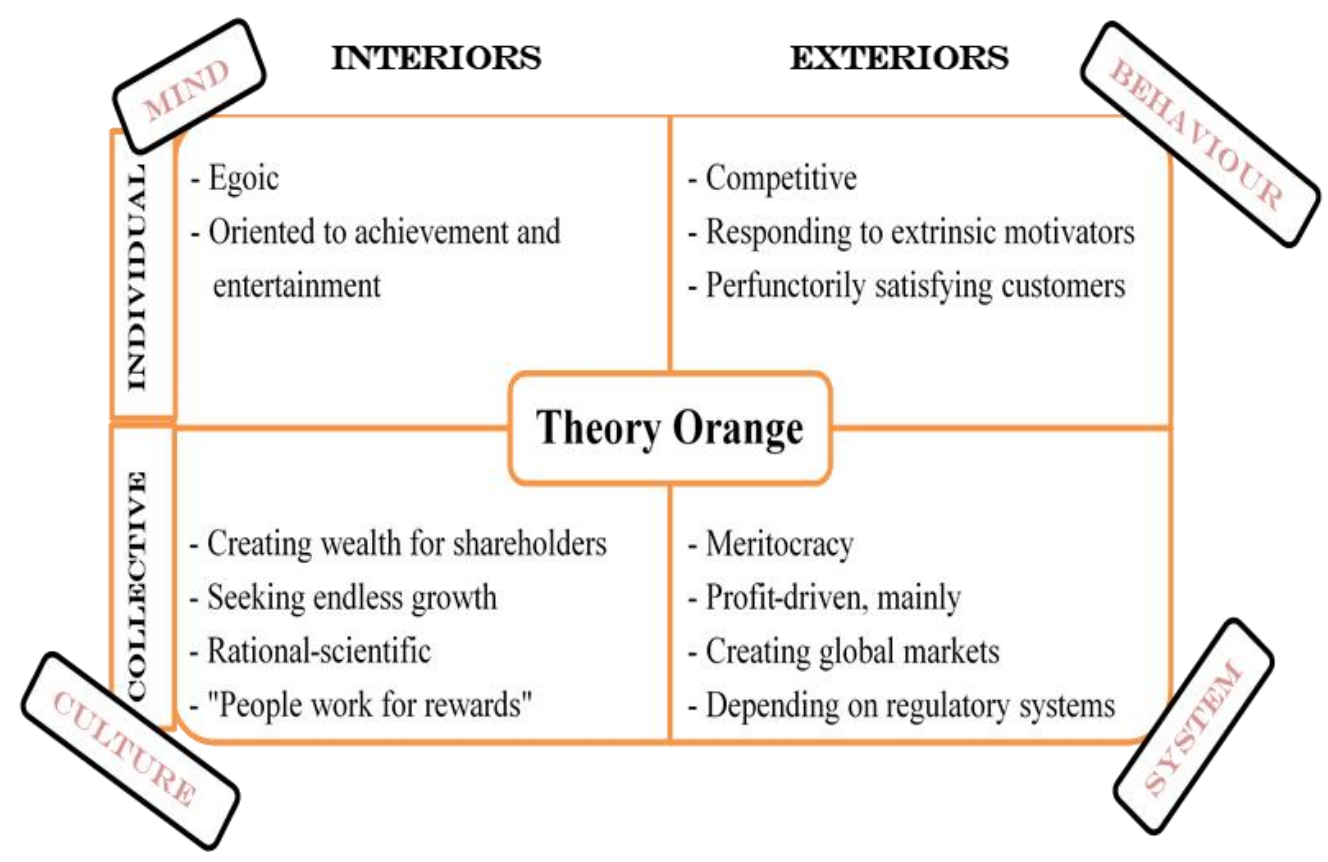

Now let us assume that the corporate world evolves two levels up to Yellow. In the Yellow level, all motivational patterns would be different.

Figure 7. Possible Theory Yellow Reality for the Corporate World

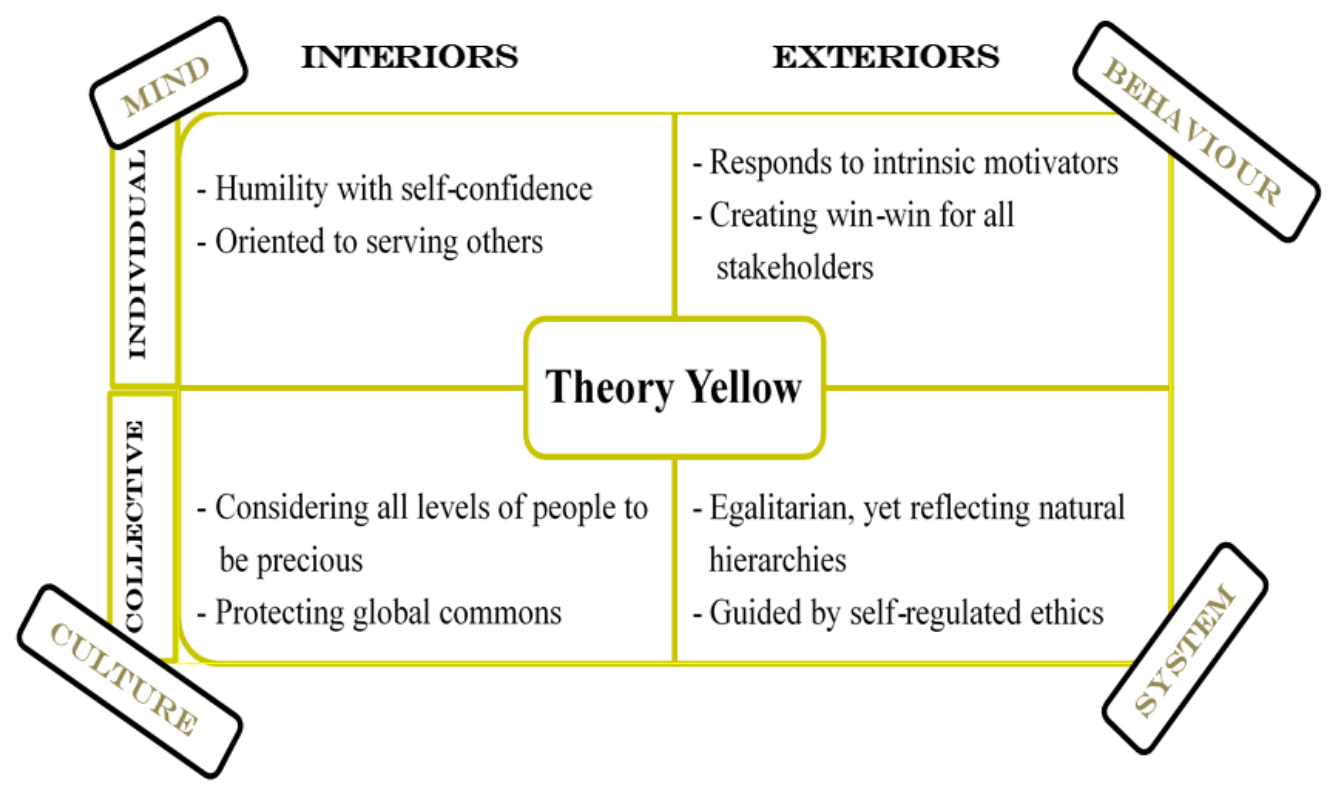

What might be the status in the four quadrants? This too bears research. Here in Figure 7 we attempt Theory Yellow. ${ }^{22}$

\footnotetext{
${ }^{22}$ Narayanan Ramanathan, Shaping the Future of Quality, Keynote address, Asian Network for Quality Congress, Singapore, 2006.
} 


\section{SPACE AND RESPONSIBILITY}

It is commonly understood that empowerment of people requires that they are provided space, such that they have room to maneuver and grow. R. Gopalakrishnan ${ }^{23}$ cites the rearing, in a Zambezi farm, of designer crocodiles that are stunted by confining them to a small space soon after hatching. He also calls stunted managers 'bonsai managers'. K. Matsushita ${ }^{24}$ would rather overrate the abilities of his employees in promoting them, so that they grow into the job. Max de Pree ${ }^{25}$ of Herman Miller is poetic in describing the role of leaders, who "owe people space, space in the sense of freedom. Freedom in the sense of enabling our gifts to be exercised ... so that we may both give and receive such beautiful things as ideas, openness, dignity, joy, healing and inclusion."

On the other hand, it is expected of employees, especially in quality-based settings, that they uphold and follow company procedures and standards. It was meant for an era when employee skills were somewhat raw. In contrast, Kondo asserts that "a single standard cannot be the most efficient for all people" and takes the example of sports. He focuses on clarifying the objective. "A strong sense of responsibility towards work cannot be created by ... telling them [employees] only how to do the work and not its purpose." For Kondo, a work standard should have three parts:

- The objectives of the work;

- Constraints on doing the work - these include safety instructions and the like, and

- The means and methods to be employed.

He proposes a minimum of restrictions, which must be scrupulously obeyed, though. In methods, Kondo leans on the side of greater autonomy, which will foster a sense of responsibility in the employee. The objective must be achieved, and it is necessary to inculcate a strong desire to achieve it.

The use of work instructions dates to 1940 when the American 'Training Within Industry' (TWI, see website) program was developed. It was picked up by Toyota in 1950, and job instructions or operation manuals became ubiquitous. Juran ${ }^{26}$ has always advocated self-control and self-inspection by workers. The Japanese practice evolved from TWI to making workers themselves write the work instructions. This must be looked at in conjunction with QC circles introduced in 1962 by Kaoru Ishikawa ${ }^{27}$ who also defined respect for humanity as enabling people to realize their potential. QC Circle Koryo ${ }^{28}$ - Fundamentals of QC Circles - outlines the first principle: "Fully reveal human capabilities and eventually draw out infinite possibilities." In the U.S these ideas have blossomed into the concept of self-managed or self-directed teams, which Juran $^{29}$ endorsed. Even earlier, the U.S. General Bill Creech, ${ }^{30}$ who claimed that he was the first to coin the term TQM, acted against centralism and created team-based structures that focused on group output or product rather than each person's job. Of late, John Shook ${ }^{31}$, as part of his work on Lean methods has described the 'A3' thinking process as providing 'pull-based authority' to

\footnotetext{
${ }^{23}$ R. Gopalakrishnan, The Case of the Bonsai Manager, Penguin Portfolio, 2007.

${ }^{24}$ Konosuke Matsushita, Not for Bread Alone, PHP Institute Inc., Japan, 1980.

${ }^{25}$ Max De Pree, Leadership is an Art, Penguin Random House, 1987.

${ }^{26}$ Joseph Moses Juran, Leadership for Quality, The Free Press, 1989.

${ }^{27}$ Kaoru Ishikawa, What is Total Quality Control the Japanese Way, Prentice Hall, 1988.

${ }^{28}$ QC Circle Headquarters, ed., (1980), QC Circle Koryo, and How to Operate QC Circle Activities, JUSE Press, upgraded translation, 2008.

29 Joseph Moses Juran, Editor-in-chief, A History of Managing for Quality, Chapter 17: A History of Managing for Quality in the United States of America, Juran, J.M., ASQC Quality Press, Milwaukee, 1995.

${ }^{30}$ Bill Creech, The Five Pillars of TQM, Truman Talley Books, New York, 1994.

${ }^{31}$ John Shook, Managing to Learn, Lean Enterprises Institute, Indian edition 2014, Lean Management Institute of India, 2008.
} 
those who solve problems. The system is designed to provide space to employees, as supervisors question, coach and teach rather than aim at command and control. These developments represent a leap forward in the empowerment of the frontline.

What about beginners? At present, companies like Renault Nissan, for example, develop exhaustive step by step instructions running into many pages for beginners. More importantly, they train new workers for dexterity in general, helping nip many known types of 'human errors' in operations in the bud. But once the worker is experienced, it is no longer necessary to straitjacket him, and this is the point Kondo makes. Noel Burch ${ }^{32}$ of Gordon Training International is said to have developed the progression of skill from unconscious incompetence to unconscious competence. (Figure 8)

Figure 8: Shu-Ha-Ri with Burch Model

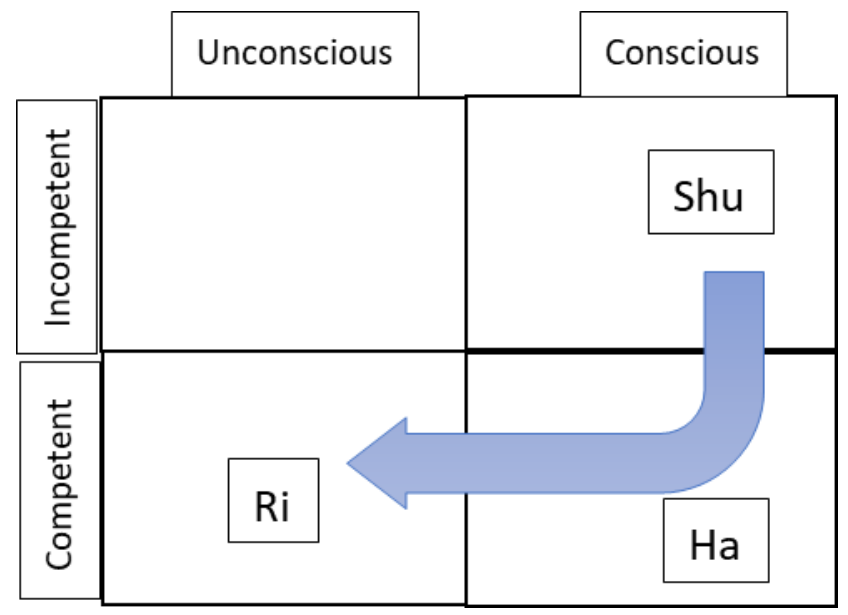

This matrix corresponds to the traditional three levels the Japanese refer to - Shu, Ha, Ri. ${ }^{33}$ The three levels somewhat match the Chinese expressions Neng, Miao, and Shen, possibly in relation to painting or calligraphy, ${ }^{34}$ as well as the three levels of the $10^{\text {th }}$ century Sanskrit Kavyamimamsa by Rajasekhara, quoted and explained by Mahesh. So, we now have three similar hierarchies (Figure 9).

These levels are, as can be seen, akin to the top three levels of Maslow. That is the conclusion of Mahesh too, in respect of the Chinese and the Indian levels, with Anupadeshika probably one intermediate stage (Green?) above Maslow's Belongingness. So, rigid instructions are required only at the early stages. Also, in the Beck \& Cowan hierarchy, the Blue level is said to be the one that expects explicit instructions from its superiors.

\footnotetext{
${ }^{32}$ Noel Burch, Gordon Training International, 1970s, described in https://www.mindtools.com/pages/article/newISS_96.html

${ }^{33}$ Hitoshi Kume, Management by Quality, Second Revised Edition, Productivity and Quality Publishing, Madras, 2009.

${ }^{34}$ Neng-Miao-Shen x5fVQPgtgkRI\&hl=en\&sa=X\&ved=0ahUKEwi3vbf08rjQAhVHpI8KHa4rCSwQ6AEIHTAB\#v=onepage\&q=shen $\% 20$ miao\%20neng\&f=false
} 
Figure 9: The three levels of competence in three Asian Traditions

\begin{tabular}{|c|c|c|}
\hline Japanese & Chinese & Indian \\
\hline $\begin{array}{c}\mathbf{R i} \\
\text { Detaching, creating completely } \\
\text { new method }\end{array}$ & $\begin{array}{c}\text { Shen } \\
\text { Hands appearing to move } \\
\text { spontaneously }\end{array}$ & $\begin{array}{c}\text { Sahaja } \\
\text { Innate, confluence, natural, easy } \\
\text { flow }\end{array}$ \\
\hline $\begin{array}{c}\text { Ha } \\
\text { Breaking, adding one's own } \\
\text { ingenuity }\end{array}$ & $\begin{array}{c}\text { Miao } \\
\text { Works in style appropriate to his } \\
\text { subject }\end{array}$ & $\begin{array}{c}\text { Aharya } \\
\text { Gotten, second nature, } \\
\text { recognition by one's own } \\
\text { standards }\end{array}$ \\
\hline $\begin{array}{c}\text { Shu } \\
\text { Adherence, Practicing the art }\end{array}$ & $\begin{array}{c}\text { Neng } \\
\text { Recognition by others }\end{array}$ & $\begin{array}{l}\text { Anupadeshika } \\
\text { Learnt, seeking recognition by } \\
\text { respected others }\end{array}$ \\
\hline
\end{tabular}

At higher levels, ownership requires great space. Taiichi Ohno, ${ }^{35}$ the great master who created the Toyota Production System, acknowledges the freedom he got. "I knew all too well," he writes, "how they worried about me and what I was doing. Yet they never said, 'Do this' or "Do that'. For my part, I never had to say, 'I'd like to do this' or 'Please let me do that.' I just did everything I thought had to be done. Had I asked permission, my resolve would have weakened because of the pressure to prove what I was doing. Had either side said anything the relationship would have collapsed."

\section{PUSHING THE BOUNDARIES OF THE COMFORT ZONE}

Further, Kondo connects the pursuit of clear objectives with alignment in the organization. He draws lessons from the sporting arena, as so much struggle and pushing at limits of pain is involved in sports, and yet it all seems worthwhile in the light of the eventual "joy of achievement." Objectives have to be challenging, therefore. Gopalakrishnan proposes handing tough assignments to aspiring managers. The objectives must encourage one to push at his/her comfort zone. Any progress or achievement seems to happen only at the boundaries of one's comfort. Inside it, there is only maintenance or even deterioration. Too far outside it, effort breaks down, and failure experiences induce giving up. The so-called stretch goals in some American schools of thought stipulate target levels that are not expected to be achieved, not realizing how dysfunctional that can get. "A goal that is beyond the means of its accomplishment," wrote Deming, "will lead to discouragement, frustration, demoralization."

In TQM, policy management is intended to achieve this fine balance of setting objectives persuasively at the edges of comfort zones. British researchers Wichter and Butterworth ${ }^{37}$ write of Hoshin that are "difficult and habit-breaking so that people should seek a different way of doing things," distinguishing these from daily management or 'business fundamentals'. Good managers create situations that involve coping with difficulties. "Because acquiring this strength entails

\footnotetext{
35 Taiichi Ohno and Setsuo Mito, Just-in-Time for Today and Tomorrow, English Edition Productivity Press, 1988, Originally in Japanese, Diamond Inc., Tokyo, 1986.

${ }^{36}$ William Edwards Deming, The New Economics, Massachusetts Institute of Technology, Center for Advanced Engineering Study, 1993.

${ }^{37}$ Barry Witcher \& Rosie Butterworth, "Hoshin Kanri in Hewlett Packard”, Journal of General Management, Vol. 25, No.4, Summer 2000, pp. 70 85.
} 
learning how to deal with mistakes," writes Tsuyoshi Saboa of Toyota Auto Body in the book TQC and $T P M^{38}$ "the company can foster it by giving people work that will force them to grow. People should consider work a vocation and should seek to discover and to develop their personal talents as early as possible."

In contrast, many companies, notwithstanding their professed stances, accept mediocre improvement targets that employees know how to negotiate - their systems of performance appraisal compel employees to adopt such stratagems, and in that process, stunt their own growth and that of the organization. The organizational theorist Chris Argyris ${ }^{39}$ even has a phrase for it skilled incompetence - behaviour people master in organizations he terms 'defensive'.

The need to repeatedly stretch the comfort zone is also illustrated in recent accounts on prevention of dementia. ${ }^{40}$ These suggest that to prevent cognitive decline it is necessary to pursue new activities, and that means doing things one hasn't done before and involving social interaction, instead of merely continuing to do, say, Sudoku. (That brings the discussion again to I-We-It.)

\section{SOCIAL NETWORK AND COLLABORATION}

A rather universal experience of those who have practiced policy management has been that departmental barriers break down, while cooperation and teamwork between departments become the norm. The concept is old. The French pioneer in management theory Henri Fayol ${ }^{41}$ reckoned that in a well-coordinated enterprise, "each department works in harmony with the rest" as against lack of coordination, which leads to "water-tight compartments."

The power of the objective-setting process is thus to promote sociality too, through productive interpersonal interactions. While objectives might be in the 'It' domain, they have a salient influence on the 'We' domain. As to the 'I' domain, objectives do stir up intrinsic motivation, and in the words of many managers, make them more comfortable taking on more responsibilities, while making work itself more enjoyable. Thus, a sensible system of setting objectives, if coupled with some freedom in target setting, can produce benefits in all the spheres of I-We-It.

Kondo is an advocate for the facilitation of inter-group interactions as a means to create and sustain motivation. Of course, QC circles are meant to promote 'mutual development'. Selfmanaged teams, likewise, are expected to take responsibility through mutual interaction. Kondo goes a step further. Rather than draw sharp boundaries between jobs, he supports widening "people's range of responsibilities, so that they overlap and create common interests with others in related areas. The resulting 'reaching out' is good for teamwork." In 'Lean' lines, it is in fact common to see workers helping those who have fallen behind or covering for a new person. In Toyota, they are critical of the swimming relay type of handover. Instead, Ohno ${ }^{42}$ prefers the track

\footnotetext{
${ }^{38}$ Shizuo Senju, ed., TQC and TPM, Asian Productivity Organization, Original in Japanese, TQC to TPM, Japan Institute of Plant Maintenance, Case on Toyota Auto Body Co. by Tsuyoshi Sabao, 1992.

${ }^{39}$ Chris Argyris, Overcoming Organizational Defenses, Prentice Hall, 1990.

40 The Telegraph Lifestyle, 19 September 2016, How to Prevent Alzheimer's Disease, by Anna Magee, http://www.telegraph.co.uk/wellbeing/health-advice/how-to-prevent-alzheimers-disease/

${ }^{41}$ Henri Fayol, General and Industrial Management, Mertino Publishing, 1916, Mansfield Centre, from publication, 1949.

42 Taiichi Ohno, Toyota Production System - Beyond Large-scale Production, Productivity Press, India. Original Japanese Edition, Toyota Seisan Hoshiki, 1978.
} 
relay type of baton exchange in overlapping zones. "Things do not necessarily run smoothly," he wrote, "just because areas of responsibility have been assigned. Teamwork is essential."

Kondo wants "all individuals and groups to maintain a strong sense of responsibility in tackling the particular jobs they have been assigned." Not just that, but they must also "maintain a strong interest in other work related to their own." He quotes a saying - 'onlookers can see better than the players' - from the Japanese board game 'Go'. Drawing on perspectives from others is therefore valuable. Joint efforts, moreover, can even tackle urgent problems that may not even be defined sharply. "Participation produces the best and most unexpected results." As Shiba ${ }^{43}$ says, groups make much of their creative contribution through the task selection process itself. Kondo also backs the idea of putting people on assignments that involve getting out and meeting people from outside the organization. That is also advocated by a whole body of literature that has emerged on networking and 'social capital' which is the collective value of all the social networks in an organization. The 'We' domain is thus a vital, inter-connected element in the paradigms of managing people.

\section{IMMERSION, GEMBA}

It is said that Shewhart had no habit of visiting the shop floor - he just looked at data. That is not the accepted idea now, for a basic principle of management centered on quality is for leaders to develop their sense of reality from the gemba, the workplace itself, and not merely from reports and presentations, or even just data. Shiba ${ }^{44}$ talks of jumping into the fishbowl, as a metaphor for understanding the context in which customers use products. He also talks of looking into the peripheries (such as the scrap yard) and not just the core of a workplace, to grasp the real rather than the showcased situation. Likewise, Gopalakrishnan talks of immersion, though he includes in it travel, talking to people and books, as well as looking at the 'surrounds' and not just the nucleus. The three 'reals', gemba (the real place), gembutsu (the real thing), and genjitsu (the real facts) have become part of standard TQM and problem-solving literature.

Being at the gemba prevents isolation of managers from their people. It is what completes the picture of reality.

\section{THE NEEDS OF EMPLOYEES}

Most organizations seldom ask what the employees need. One way of classifying the needs would be to put them under four heads, Experiencing, Learning, Contributing and Growth, ELCG for short. Not all these needs are at the same level in, say, Maslow's hierarchy. Safety could be at level two. Fairness and justice probably straddle levels 2 and 3. Joy (not just fun) on the other hand might be a need at Levels 4 or 5. One basic assumption in this construct is that everyone wants to contribute to the organization and know that his/her work makes a difference. This is the other side of 'performance' that companies, especially at the Orange level, expect to extract from employees, when all the while the willingness to contribute exists, unless stymied by organizational

\footnotetext{
${ }^{43}$ Shoji Shiba, Alan Graham and David Walden, A New American TQM, Productivity Press, Portland, Oregon, 1993. ${ }^{44}$ Shoji, Shiba and David Walden, Four Practical Revolutions in Management, Productivity Press, Portland, Oregon, 2001.
} 
pathologies. Csikszentmihalyi ${ }^{45}$ shows that people need freedom from distraction, and frequent access to results to be in a 'flow' - which could be equated to Maslow's Level 5, self-actualization. The world of phone messaging and emails, where attention spans are shrinking, and time is getting fragmented might act against flow. Figure 10 shows the needs classified by SRF in the year 2000. It is not quite arranged by natural hierarchies but is still a comprehensive one for creating motivating conditions.

Figure 10: ELCG Needs
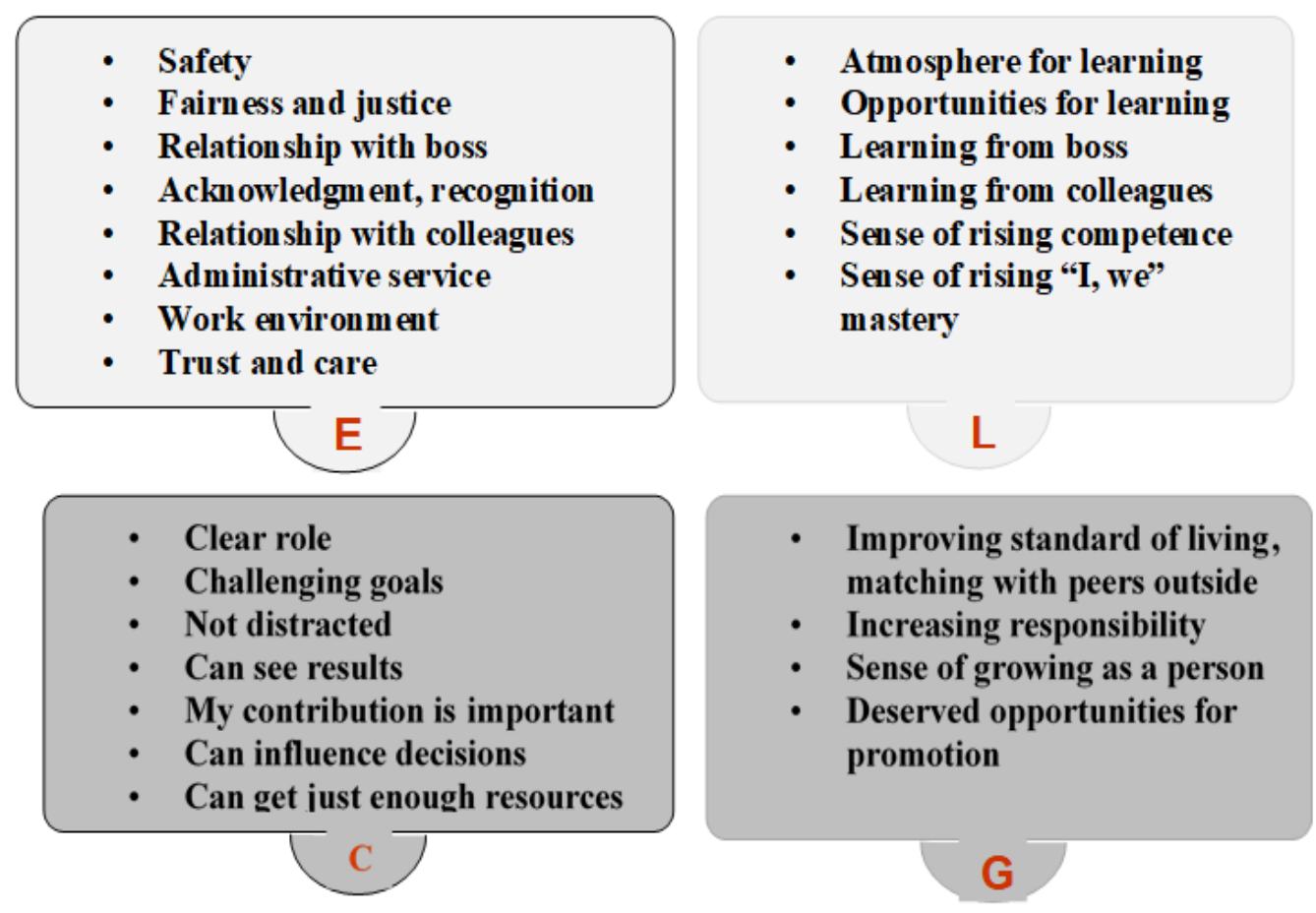

This model stresses learning and personal growth. Learning is not only a necessity for the organization, but for every individual, however dormant such a need might be. And genuine learning has to span all the dimensions of I-We-It. For example, this author, working on a people development system in 1995 for SRF produced a diagram (Figure 11) that exemplifies the threepronged visualization, and uses some terms from Senge. ${ }^{46}$

Learning systems must encourage on-the-job-training (OJT), self-development and mutual-development, for learning takes place not only from feedback (as McGregor insisted) but also from sharing and coaching. OJT is a form of coaching by the immediate superior, who sets high expectations, but tends to ask questions rather than provide answers. ${ }^{47}$

\footnotetext{
${ }^{45}$ Csikszentmihalyi, Mihaly, Flow, Harper Perennial, 1990.

${ }^{46}$ Peter Senge, The Fifth Discipline, Doubleday Currency,1990,

${ }^{47}$ John Shook, Managing to Learn, Lean Enterprises Institute, Indian edition 2014, Lean Management Institute of India, 2008.
} 


\section{PERFORMANCE}

Quality Management is by itself the performance management system. Companies that practice both TQM and the western style appraisal-based performance management systems cause great confusion within. TQM is more concerned with organizational performance, while the AngloSaxon way is to manage individual performances. Deming ${ }^{48}$ was probably the first among quality thinkers who denounced performance appraisal systems and their damaging consequences. He was poignant in mapping these 'forces of destruction' from childhood through the whole of one's life, which ignored the point that "one is born with intrinsic motivation, self-esteem, dignity, cooperation, curiosity, joy-in-learning."

Figure 11: Model for Development, SRF

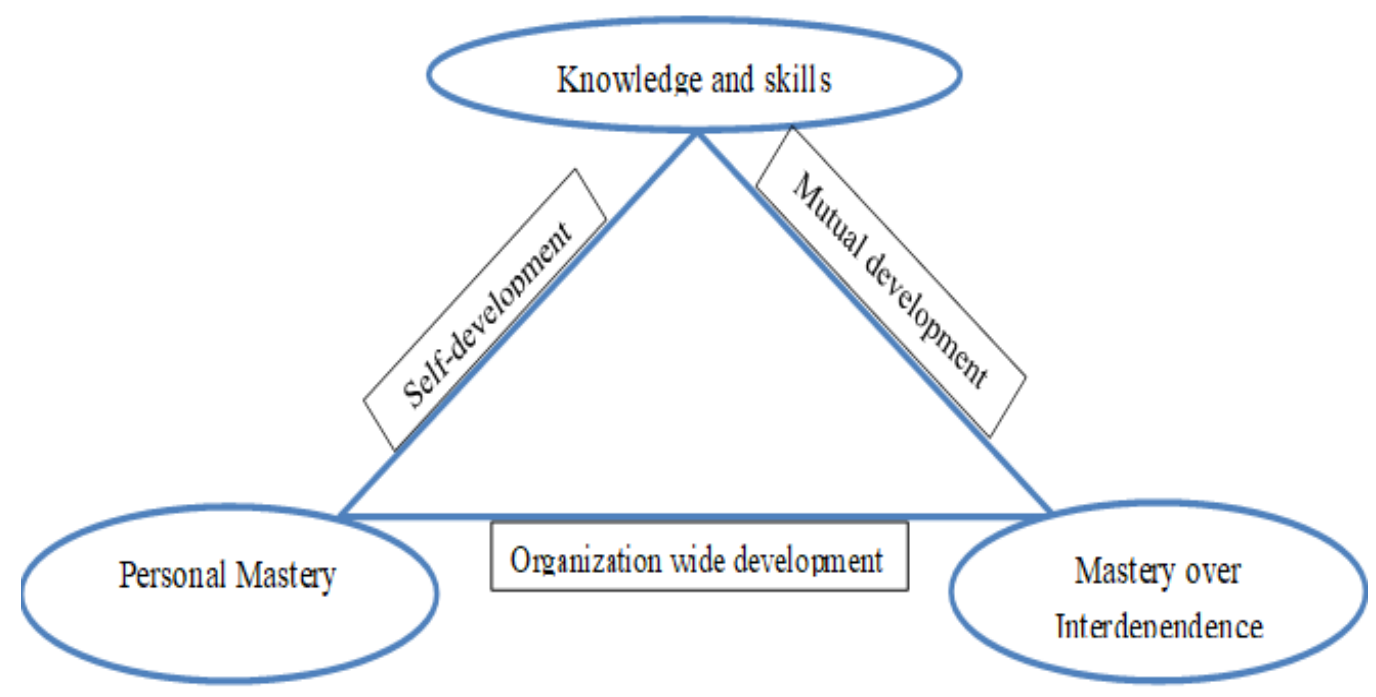

Outside of quality management, Alfie $\mathrm{Kohn}^{49}$ and many others cite volumes of research studies that prove the futility and harm from reward and punishment systems. In this paper, we touch this topic only briefly. The pervasive kind of performance management systems we encounter is a product of the Orange Level, one might call it its superstition. Until the corporate world breaks out of the Orange Level, money as the primary reward, satisfier and motivator will likely stay, no matter what Herzberg said.

\footnotetext{
48 William Edwards Deming, The New Economics, Massachusetts Institute of Technology, Center for Advanced Engineering Study, 1993.

${ }^{49}$ Alfie Kohn, Punished by Rewards, Houghton Mifflin Company, Boston, New York, 1993.
} 
Figure 12: Performance and capability

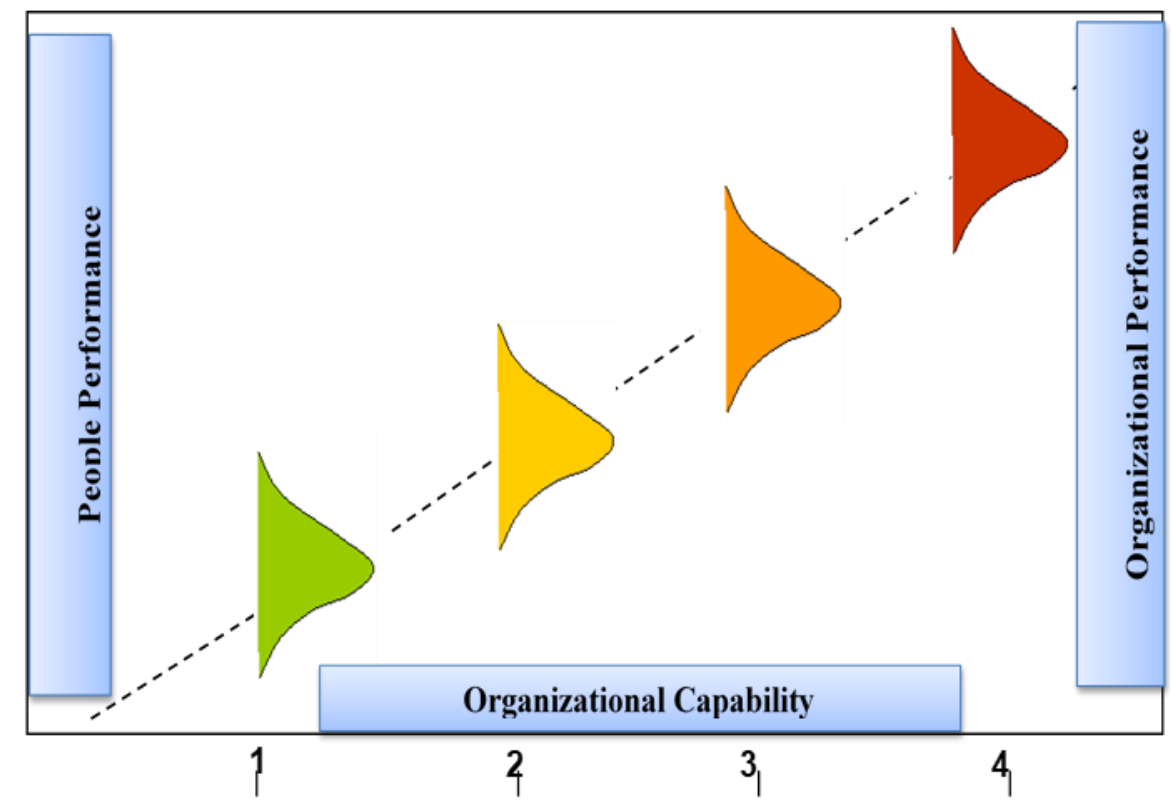

Individual performance is in fact a variable that depends on organizational capability. Societies at higher levels of the natural hierarchies tend to put out individuals who soar and produce great thoughts and effects. Capability too is a hierarchy. There may be expected ranges of performance within each level of capability. The 'best performers' in low capability organizations may function at a lower level of maturity than the poorer ones in a high-capability structure. ${ }^{50}$ The concept is depicted in Figure 12.

A large number of people function at the level of belongingness. Here, recognition is an important need. There are three aspects to this approach - acknowledgement (based on valuing people for what they are, unconditionally), recognition (based on honouring people for the wonderful work they do), and celebration (based on rejoicing together over achievement, or for no reason at all) - called by the acronym ARC. ${ }^{51}$ For those above belonginess level, paying for performance can scarcely work and in fact suppresses their higher order needs. In contrast, ARC, by honouring people, spurs everyone to excellence. ARC can help burn the neuroses at the safety level, while performance pay taps into that very neurosis.

\section{HAPPINESS}

Performance and happiness may be said to be the two effects that the process of managing people must produce. In some organizations, there is objection to the use of the term 'happiness'. They would settle for 'satisfaction' instead. Companies generally lack a method of measuring subjective happiness, though they do surveys, just as they rarely comprehend performance for all

\footnotetext{
${ }^{50}$ Narayanan Ramanathan, The Five Stages of Organizational Capability, Keynote address, Asian Network for Quality Congress, Taipei, 2005.

${ }^{51}$ Narayanan Ramanathan, Recognition versus Performance Appraisal: An Evaluation, Asian Network for Quality Congress, Bangkok, 2008.
} 
the systems they have for 'managing' it. HR surveys confound diagnostic purposes with control. The former is meant to know what might be problem areas. The latter is for knowing whether people-management actions have been effective. For diagnosis, surveys are not particularly useful, and a host of methods, including interactions at the gemba are more effective. The concept of control surveys is not understood. Figure 13 is an example of trend results from a control-type survey in a plant with over 1500 employees. This is a sample survey every quarter, which was started when there existed a severely adverse relationship with frontline workers.

Figure 13: Trend of binary score of happiness

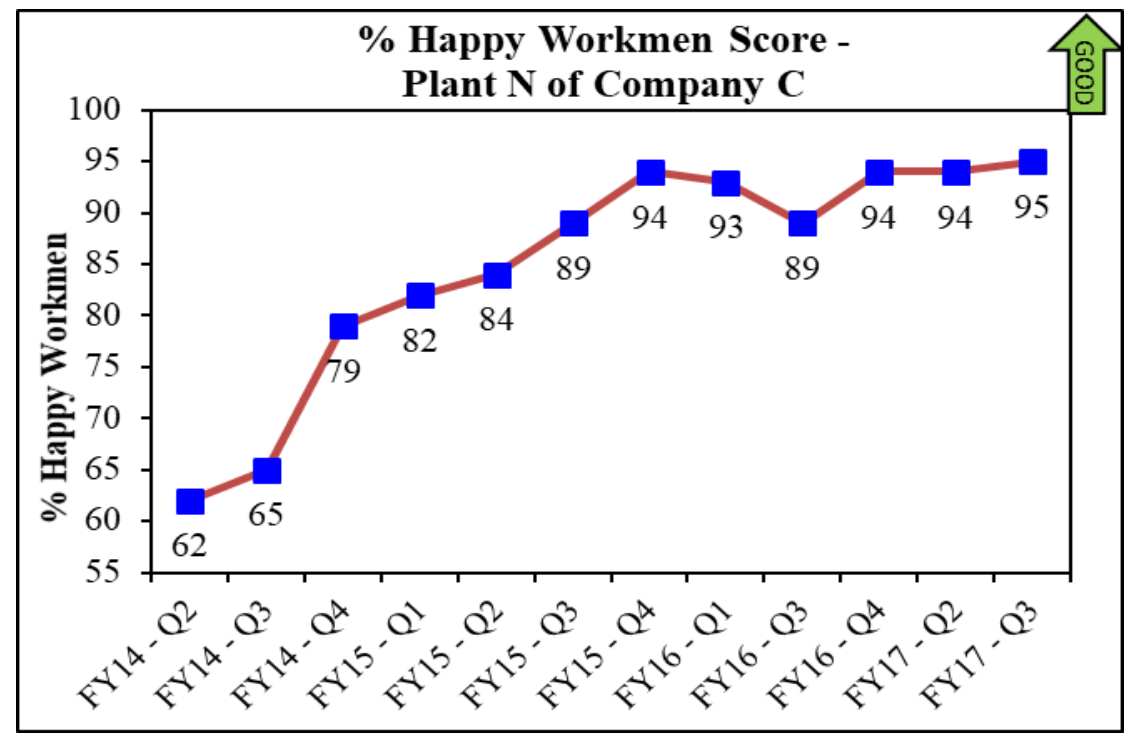

A trust building program that applied some of the paradigms in this paper was launched and progress measured. The program included three-day workshops for mixed groups of workers and managers focused on I and We, that is, the subjective world. That means no 'behavioral science' techniques that merely target the exterior-observable phenomena. A system called the "Red Book' proactively ferreted out and resolved thousands of mostly petty irritants. Strain in work practices was cut down through thousands of kaizens that involved the workmen too. All these created conditions for more fruitful dialogue. Figure 13 is a graph of the percentage answering 'yes' to the question: "Overall, I am happy working in xxx company." The choice was only yes/no, and the vote is secret. The score went up from a precarious 62 percent to 95 . For such a survey, the perfect score of 100 is an achievable ideal. Clearly however, the worst was behind for this plant.

\section{CONCLUSION}

What we now have is a set of paradigms of managing people in organizations. These are not what one might expect to read in HR text books. The integration of the subjective and the objective in both individual and collective domains is a first step. This is not a simple step as the denial by Modernity of the reality of the subjective has first to be overcome. The worlds are different at each level of the natural hierarchies of human existence. Combining these concepts is 
therefore essential, but a whole lot of work remains to be done in this field. Empowerment has been a buzzword for long, but its realization requires managers to provide space to their employees, facilitating ownership and responsibility-taking. Furthermore, conditions that encourage people to push at the boundaries of their comfort zones have to be promoted, so that challenging goals are taken. Socialization that promotes the I and We dimensions, and a culture of immersion in the gemba, and addressing the ELCG needs of employees are essential to create great people organizations. Individual performance can be seen as a function of the level of organizational capability. All of TQM is about creating extraordinary organizational capability and performance. So, in place of performance appraisals that are often destructive, ARC - acknowledgement, recognition and celebration - may not only lead to high-performance organizations but also happier ones. And yes, the state of happiness can be measured and improved!

\section{Sažetak:}

\section{PARADIGME U UPRAVLJANJU LJUDIMA: U ČAST YOSHIOU KONDU}

Kad je Yoshio Kondo izabran za počasnog člana ASQ - American Society for Quality (Američkog društva za kvalitetu) 2004. godine, u obrazloženju je istaknut njegov izvanredan doprinos ljudskoj motivaciji $i$ potpunom upravljanju kvalitetom. Njegova knjiga na japanskom jeziku „,Ohanashi Motivation “, objavljena 1989. godine, ubrzo je prevedena na engleski jezik 1991. godine kao „Human Motivation“ (Ljudska motivacija). Kondo kao veliki znanstvenik, u svojoj knjizi najprije govori o doprinosu svojih prethodnika, posebno Eizabura Nishiborija, Abrahama Maslowa, Fredericka Herzberga i Jamesa O'Toolea. Nishiborijev trojedini model uključuje kreativnost, fizičku aktivnost i društvenost. Ovaj model odgovara Ja-Mi-To trijadi Kena Wilbera, što ima duboke implikacije za izbjegavanje fragmentiranog pogleda na čovječanstvo. $U$ suradnji s Japanskom asocijacijom za standardizaciju, Kondo je redefinirao standard tako da, iako su ciljevi razjašnjeni i utvrđuju ograničenja, standard pojedincima pruža bitnu slobodu, osim početnicima. Ovaj koncept otvara prostor, toliko važan za ljudski rast. S druge strane, kreativno odstupanje od pravila predviđeno je u hijerarhiji shu-ha-ri na japanskom, s ekvivalentima u kineskoj i indijskoj tradiciji. Ne samo što smisleni ciljevi vode ka većoj usklađenosti, već potiču i veće zanimanje za ono što rade druge povezane grupe, pomažući u izgradnji zajedništva i timskog rada u organizaciji. Kondo istražuje sportsku aktivnost kako bi izvukao pouke za rad, jer kao i u sportu, borba povećava "radost postignuća". To je slično konceptu pomicanja granica zona udobnosti kako bismo postigli bilo što vrijedno. Pored navedenih koncepata, moglo bi se razmotriti unutarnju motivaciju (Deming), prirodne hijerarhije u ljudskom postojanju (Gebser, Graves), kao i ideju uranjanja u gembu (Shiba). To upućuje na razumijevanje istinskih potreba ljudi na različitim razinama postojanja i načine stvaranja zamaha u organizaciji $i$, naravno, uspješnosti. Treba biti jasno da organizacijska uspješnost nije zbroj pojedinačnih, već razina sposobnosti organizacije zapravo određuje raspon mogućih performansi. Kad su sva tri elementa Ja-Mi-To razumno uravnoteženi, ljudi osjećaju da su zapravo 'sretni' radeći u svojoj organizaciji. Ovaj rad će prikazati stvarne brojke koje iz toga proizlaze, te istražiti paradigme koje su osmilili velikani upravljanja ljudima, kako u literaturi tako $i$ u praktičnom djelovanju.

Ključne riječi: Ja-Mi-To, prirodna hijerarhija, prostor, zona udobnosti, unutarnja motivacija. 
Meanings of Japanese Words Used

(with Japanese characters)

\begin{tabular}{|l|l|l|}
\hline \multicolumn{1}{|c|}{$\begin{array}{c}\text { Roman letters } \\
\text { (Romaji) }\end{array}$} & \multicolumn{1}{|c|}{$\begin{array}{c}\text { Japanese Characters } \\
\text { (Kanji) }\end{array}$} & \multicolumn{1}{c|}{ Meaning } \\
\hline Ohanashi & お話 & A story, a tale \\
\hline Bonsai & 盆栽 & (Miniature) potted plant \\
\hline Shu, Ha, Ri & 守破離 & $\begin{array}{l}\text { Three stages of mastery: the fundamentals, breaking } \\
\text { with tradition, parting with traditional wisdom }\end{array}$ \\
\hline Genba (also spelt gemba) & 現場 & On the spot \\
\hline $\begin{array}{l}\text { Genbutsu (also spelt } \\
\text { gembutsu) }\end{array}$ & 現物 & Real thing \\
\hline Genjitsu & 現実 & Actuality, reality \\
\hline Kaizen & 改善 & Improvement \\
\hline
\end{tabular}

Courtesy Yukihiro Ando

\section{REFERENCES}

1. Argyris, C., Overcoming Organizational Defenses, Prentice Hall, 1990.

2. Beck, D. E. \& Cowan, C. C., Spiral Dynamics, Blackwell Publishing, 1996, Paperback edition, 2006.

3. Block, P., The Empowered Manager, 1987, John Wiley \& Sons, New Edition, 1991.

4. Creech, B., The Five Pillars of TQM, Truman Talley Books, New York, 1994.

5. Csikszentmihalyi, M., Flow, Harper Perennial, 1990.

6. De Pree, M., Leadership is an Art, Penguin Random House, 1987.

7. Deming, W. E., The New Economics, Massachusetts Institute of Technology, Center for Advanced Engineering Study, 1993.

8. Einstein, A., Ideas and Opinions, Rupa \& Co. 1979, 12th impression 1995, Copyright Crown Publishers, 1954.

9. Erikson, E. H., Childhood and Society, 1950, W. W. Norton \& Co., reprint by Penguin Books, England, 1973.

10. Fayol, H., General and Industrial Management, Mertino Publishing, 1916, Mansfield Centre, from a 1949 publication.

11. Gebser, J., 1949, 1953, The Ever-Present Origin, Ohio University Press, Athens, English Translation, 1985.

12. Gopalakrishnan, R., The Case of the Bonsai Manager, Penguin Portfolio, 2007.

13. Graves, C. W., Levels of Human Existence, 2002, from transcribed notes of a 1971 Graves seminar by William R. Lee, ECLET Publishing, $5^{\text {th }}$ Reprint, with Foreword by Christopher Cowan, 2009.

14. Graves, C. W., Madden, H. Madden and P. Lynn, The Congruent Management Strategy, From the Historical collection of the work of Dr Clare Graves by William R. Lee, 1970. www.claregraves.com

15. Herzberg, F., One More Time: How do you Motivate Employees, Harvard Business Press, 2003, Boston, 2008, Harvard Business Review Classics.

16. Ishikawa, What is Total Quality Control the Japanese Way, Prentice Hall, 1988.

17. Juran, J. M., Leadership for Quality, The Free Press, 1989. 
18. Juran, J. M., Editor-in-chief, A History of Managing for Quality, Chapter 17: A History of Managing for Quality in the United States of America, Juran, J. M., ASQC Quality Press, Milwaukee, 1995.

19. Kohn, A., Punished by Rewards, Houghton Mifflin Company, Boston, New York, 1993.

20. Kondo, Y., Ed., Human Motivation, 3A Corporation, Tokyo, 1991, originally published in Japan as Ohanashi Motivation, Japanese Standards Association, 1989.

21. Kume, H., Management by Quality, Second Revised Edition, Productivity and Quality Publishing, Madras, 2009.

22. Mahesh, V. S., Thresholds of Motivation, Tata McGraw Hill, New Delhi, 1993.

23. Maslow, A., Toward a Psychology of Being, 1954, Third Edition Wiley, Kindle Edition, 1988.

24. Maslow, A., Motivation and Personality, 1962, Third Edition, Longman, 1987.

25. Matsushita, K., Not for Bread Alone, PHP Institute Inc., Japan, 1980.

26. McGregor, D., The Human Side of Enterprise, Tata McGraw Hill, 1960, $7^{\text {th }}$ Reprint, 1983.

27. Ohno, T., Toyota Production System - Beyond Large-scale Production, Productivity Press, India. Original Japanese Edition, Toyota Seisan Hoshiki, 1978.

28. Ohno, T., with Mito, Setsuo, 1988, Just-in-Time for Today and Tomorrow, English Edition Productivity Press, Originally in Japanese, Diamond Inc., Tokyo, 1986.

29. Piaget, J., The Essential Piaget, Basic Books, New York, 1977.

30. Polanyi, M., 1958, 1962, Personal Knowledge, The University of Chicago Press, Paperback edition, 1974.

31. QC Circle Headquarters, ed., (1980), QC Circle Koryo, and How to Operate QC Circle Activities, JUSE Press, upgraded translation, 2008.

32. Ramanathan, N., The Five Stages of Organizational Capability, Keynote address, Asian Network for Quality Congress, Taipei, 2005.

33. Ramanathan, N., Shaping the Future of Quality, Keynote address, Asian Network for Quality Congress, Singapore, 2006.

34. Ramanathan, N., Recognition versus Performance Appraisal: An Evaluation, Asian Network for Quality Congress, Bangkok, 2008.

35. Ramanathan, N., The I-We-It of Adaptability, Paper presented in EOQ Congress, Gothenburg, 2014.

36. Shiba, S., Graham, A. and D. Walden, A New American TQM, Productivity Press, Portland, Oregon, 1993.

37. Shiba, S. and D. Walden, Four Practical Revolutions in Management, Productivity Press, Portland, Oregon, 2001.

38. Senge, P., The Fifth Discipline, Doubleday Currency, 1990.

39. Senju, S., ed., TQC and TPM, Asian Productivity Organization, Original in Japanese, TQC to TPM, Japan Institute of Plant Maintenance, Case on Toyota Auto Body Co. by Tsuyoshi Sabao, 1992.

40. Shook, J., Managing to Learn, Lean Enterprises Institute, 2008, Indian edition Lean Management Institute of India, 2014.

41. Tejomayananda, S. Translation and commentary, Tattvabodha, Adi Shankara's Sanskrit text of $8^{\text {th }}$ century C.E., Central Chinmay Mission Trust, 2005.

42. Wilber, K., Sex, Ecology, Spirituality, Shambhala, Boston \& London, 1995, $2^{\text {nd }}$ edition, 2000.

43. Wilber, K., A Brief History of Everything, Shambhala, Boston, 1996, $2^{\text {nd }}$ edition, 2000.

44. Witcher, B. \& R. Butterworth, Hoshin Kanri in Hewlett Packard, Journal of General Management, Vol 25, No.4, Summer 2000. 


\section{Internet:}

1. Burch, Noel, Gordon Training International, 1970s, described in https://www.mindtools.com/pages/article/newISS_96.html

2. Neng-Miao-Shen x5fVQPgtgkRI\&hl=en\&sa=X\&ved=0ahUKEwi3vbf08rjQAhVHpI8KHa4rCSwQ6AEIHTA $\mathrm{B} \# \mathrm{v}=$ onepage $\& \mathrm{q}=$ shen $\% 20 \mathrm{miao} \% 20$ neng $\& \mathrm{f}=$ false

3. The Telegraph Lifestyle, 19 September 2016, How to Prevent Alzheimer's Disease, by Anna Magee, http://www.telegraph.co.uk/wellbeing/health-advice/how-to-prevent-alzheimersdisease/

4. TWI Institute, Training Within Industry, http://twi-institute.org/training-within-industry/

5. Forbes, 22 September 2014, 4 Reasons Why Social Capital Trumps All, https://www.forbes.com/sites/chriscancialosi/2014/09/22/4-reasons-social-capital-trumpsall/\#2c0aed8d6986 